Article

\title{
Inducing the Effect of a $\mathrm{Ga}_{2} \mathrm{O}_{3}$ Nano-Particle on the $\mathrm{CsF}-\mathrm{RbF}-\mathrm{AlF}_{3}$ Flux for Brazing Aluminum to Carbon Steels
}

\author{
Zhen Yao ${ }^{\circledR}$, Songbai Xue *®) Jinlong Yang and Junxiong Zhang \\ College of Materials Science and Technology, Nanjing University of Aeronautics and Astronautics, Nanjing \\ 210016, China; yaozhen123@nuaa.edu.cn (Z.Y.); yangjinloong@163.com (J.Y.); zhangjunxiong126@163.com (J.Z.) \\ * Correspondence: xuesb@nuaa.edu.cn; Tel.: +86-025-8489-6070
}

Received: 15 January 2020; Accepted: 5 March 2020; Published: 7 March 2020

check for updates

\begin{abstract}
In this study, a $\mathrm{Ga}_{2} \mathrm{O}_{3}$ nano-particle was added into $\mathrm{CsF}-\mathrm{RbF}-\mathrm{AlF}_{3}$ flux to develop a highly active flux for brazing aluminum alloy to steel, and the spreadability and wettability of $\mathrm{Zn}$-Al filler metal that matched the $\mathrm{CsF}-\mathrm{RbF}-\mathrm{AlF}_{3}$ flux-doped $\mathrm{Ga}_{2} \mathrm{O}_{3}$ nano-particle on the steel were investigated. The results showed that the spreadability and wettability of the $\mathrm{CsF}-\mathrm{RbF}_{-} \mathrm{AlF}_{3}$ flux-doped $\mathrm{Ga}_{2} \mathrm{O}_{3}$ nano-particle could be remarkably improved when matching $\mathrm{Zn}$ - $\mathrm{Al}$ filler metals on both aluminum and low-carbon steel, for which the optimal content is in the range of $0.001-0.003 \mathrm{wt} \%$ of $\mathrm{Ga}_{2} \mathrm{O}_{3}$. An investigation and analysis on the mechanism of reactions among CsF- $\mathrm{RbF}-\mathrm{AlF}_{3}-\mathrm{doped}$ $\mathrm{Ga}_{2} \mathrm{O}_{3}$ nano-particle flux and filler metal or base metals showed that the $\mathrm{Ga}_{2} \mathrm{O}_{3}$ nano-particle is selectively absorbed by the interface of molten $\mathrm{Zn}-2 \mathrm{Al}$ filler metal and base metal, which released the surface-active element $\mathrm{Ga}$ to enrich the molten $\mathrm{Zn}-2 \mathrm{Al}$ filler metal and decreased the interfacial tension, so as to promote the enlargement of its spreading area during the brazing process. It was concluded that adding a trace amount of $\mathrm{Ga}_{2} \mathrm{O}_{3}$ nano-particle into $\mathrm{CsF}-\mathrm{RbF}-\mathrm{AlF}_{3}$ flux is a meaningful way to improve the activity of flux for brazing aluminum to steel compared with adding $\mathrm{ZnCl}_{2}$, which poses the risk of corrosion on aluminum.
\end{abstract}

Keywords: $\mathrm{Ga}_{2} \mathrm{O}_{3}$; flux; $\mathrm{Zn}-\mathrm{Al}$ filler metal; wettability; spreadability

\section{Introduction}

Brazing or welding $\mathrm{Al}$ to steel has become a hot subject in recent years because Al-steel composite metal materials have been found to have wide applications in industry. In order to develop brazing

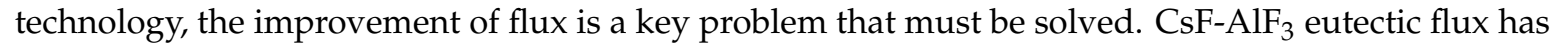
been widely used in brazing aluminum alloys [1] and exhibits an excellent performance in brazing dissimilar metals matched with $\mathrm{Zn}-\mathrm{Al}$ filler [2,3], such as brazing $\mathrm{Al}$ to $\mathrm{Al}$ [4] and $\mathrm{Al}$ to $\mathrm{Cu}$ [5]. However, $\mathrm{CsF}_{\mathrm{AlF}}$ flux is not so good when brazing aluminum to steel, and the activity of removing the oxides on $\mathrm{Al}$ and steel simultaneously needs to be improved.

It was reported that matching $\mathrm{CsF}-\mathrm{RbF}-\mathrm{AlF}_{3}$ flux and the 6061 aluminum alloy to 304 stainless steel can be executed [6]. According to Ref. [7], adding $6 \mathrm{~mol} \%$ of $\mathrm{ZnCl}_{2}$ enhanced the activity of CsF- $\mathrm{AlF}_{3}$ when removing the alumina during brazing. It is well known that the $\mathrm{Cl}^{-}$ion is a harmful ion to aluminum and steel, so developing a novel flux without a $\mathrm{Cl}^{-}$ion as an activator represents meaningful work.

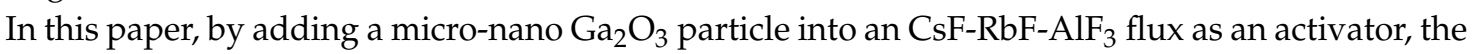
spreadability and wettability of $\mathrm{Zn}$-Al filler metal on the aluminum, along with steel, were investigated. XDR analysis and the reaction mechanism were also studied. The results would be helpful for brazing AA5052 to Q235 steel, without the risk of Cl-ion corrosion. 


\section{Materials and Methods}

The experimental base metals used for spreading tests were commercially supplied AA5052 and Q235 steel (Changshu Huayin Filler Metals Co., Ltd., Suzhou, China) with dimensions of $50 \mathrm{~mm} \times$ $50 \mathrm{~mm} \times 3 \mathrm{~mm}$. The filler metal was a $2 \mathrm{~mm}$ diameter commercial Zn-2Al alloy wire (Zhejiang Xinrui Welding Materials Co., Ltd., Shengzhou, China). The flux used in this research was prepared using nano $\mathrm{Ga}_{2} \mathrm{O}_{3}$ powder, $\mathrm{RbF}$ (AR purity, Shanghai Jiuyi Chemical Reagent Company, Shanghai, China), and commercial CsF-AlF 3 flux (Zhejiang Xinrui Welding Materials Co., Ltd., Shengzhou, China). A total of $0.5 \mathrm{wt} \%$ of $\mathrm{RbF}$ and nano $\mathrm{Ga}_{2} \mathrm{O}_{3}$ powder in the range of $0.0001-0.1 \mathrm{wt} . \%$ were added to

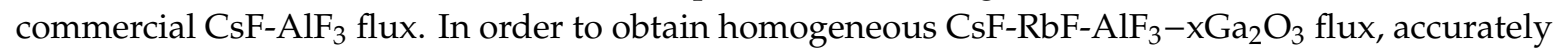

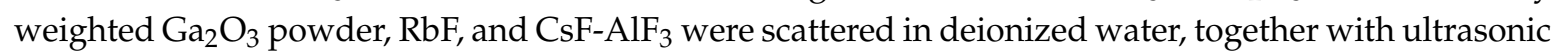
concussion, for an hour, in which the weight deviations of $\mathrm{Ga}_{2} \mathrm{O}_{3}$ and $\mathrm{RbF}$ were controlled to $\pm 1 \mathrm{mg}$. For experimenting conveniently, all specimens were pretreated: they were degreased with acetone, oxides were removed with $\mathrm{NaOH}$ solution for AA5052 and $\mathrm{HCl}$ for Q235 steel, and the specimens were then washed with deionized water and dried naturally.

The spreading test was carried out according to China's National Standard GB/T11364-2008. A total of $0.12 \mathrm{~g}$ filler metal was placed on base metal, covered with the prepared $\mathrm{CsF}-\mathrm{RbF}-\mathrm{AlF}_{3}-\mathrm{Ga}_{2} \mathrm{O}_{3}$ flux, and put into the VULCAN3-130 muffle furnace (Nanjing University of Aeronautics and Astronautics, Nanjing, China) holding at $600{ }^{\circ} \mathrm{C}$ for $60 \mathrm{~s}$. To obtain accurate results, each flux was tested five times in the same conditions. The flux residue formed during the test was carefully sampled. Then, the experimental specimens were completely cleaned with hot deionized water and dried naturally. The $\mathrm{Ga}_{2} \mathrm{O}_{3}$ particle was tested by a Hitachi S- 4800 SEM (Ningbo Institute of Materials Technology\&Engineering, Ningbo, China), and by using the energy spectrum device (energy dispersion X-ray spectrometry, EDX) attached to the equipment, microstructure observation and joint composition analysis were carried out on the solder and joint samples. The spreading areas of filler metals were measured and calculated by Image Pro-plus software, and the flux residue was analyzed with a Bruker D8 XRD analyzer (Ningbo Institute of Materials Technology\&Engineering, Ningbo, China).

\section{Results and Discussion}

\subsection{Morphology and Size of the $\mathrm{Ga}_{2} \mathrm{O}_{3}$ Micro-Nano Particle}

In order to improve the activity of $\mathrm{CsF}-\mathrm{RbF}-\mathrm{AlF}_{3}$ flux, the particle size of added $\mathrm{Ga}_{2} \mathrm{O}_{3}$ has to be small enough. A range from 100 nano-meters to several microns is perfect. The size of the $\mathrm{Ga}_{2} \mathrm{O}_{3}$ particle was tested by SEM, and the results are shown in Figure 1, in which the size of the particle is below $5 \mu \mathrm{m}$. The EDX elemental mapping of $\mathrm{Ga}_{2} \mathrm{O}_{3}$ particles is shown in Figure 2. It was previously reported [8] that $\mathrm{Ga}_{2} \mathrm{O}_{3}$ particles presenting as short rods have more importance in the integrality of the crystal structure than those presenting as long cylinders.

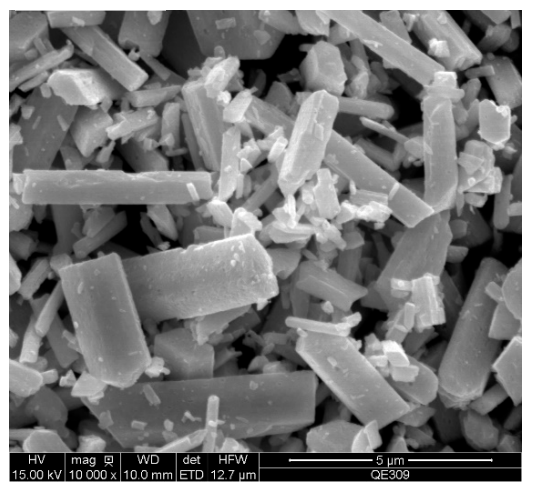

(a)

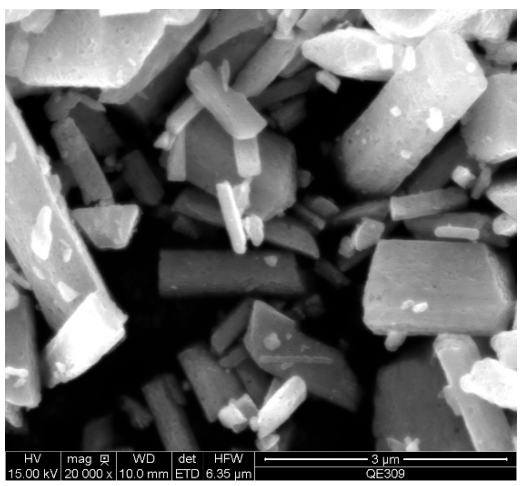

(b)

Figure 1. Morphology of $\mathrm{Ga}_{2} \mathrm{O}_{3}$ particles: (a) 10,000 times; (b) 20,000 times. 


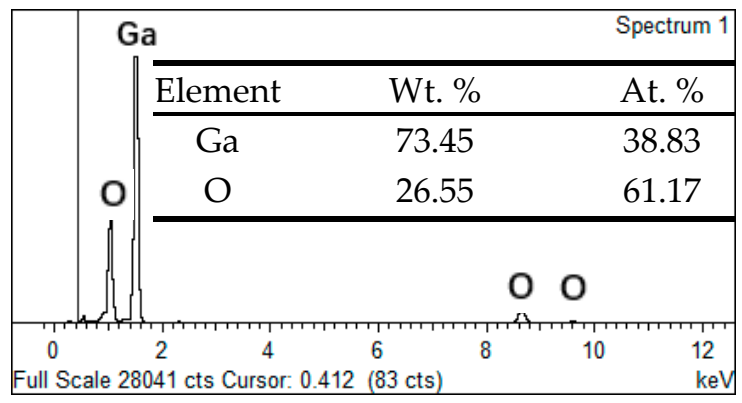

Figure 2. EDX elemental mapping of $\mathrm{Ga}_{2} \mathrm{O}_{3}$ particles.

\subsection{Application Properties of the $\mathrm{Zn}-2 \mathrm{Al}$ Filler Metal}

For determining the effect of the $\mathrm{Ga}_{2} \mathrm{O}_{3}$ particle on the spreadability and wettability of $\mathrm{Zn}-2 \mathrm{Al}$ filler metal, tests were carried out over 5052 aluminum and Q235 low-carbon steel with the new flux, whose spreading areas were measured and averaged. Figure 3 shows the relationship between the $\mathrm{Ga}_{2} \mathrm{O}_{3}$ concentration and spreading areas, and partial spreading tested graphs are presented in Figure 4.

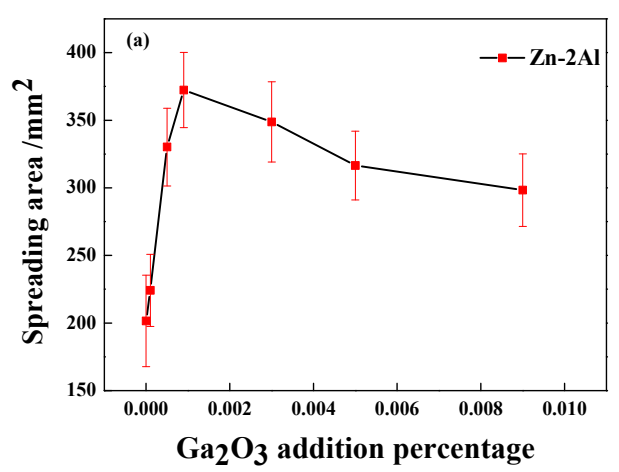

(a)

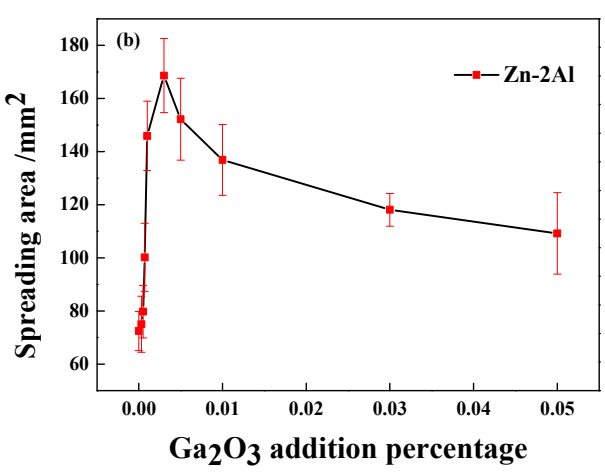

(b)

Figure 3. Effect of the $\mathrm{Ga}_{2} \mathrm{O}_{3}$ concentration on spreading areas of $\mathrm{Zn}-2 \mathrm{Al}$ filler metal on base metal: (a) 5052 aluminum; (b) Q235 low-carbon steel.

Figure 3 indicates that $\mathrm{Ga}_{2} \mathrm{O}_{3}$ addition to the $\mathrm{CsF}-\mathrm{RbF}-\mathrm{AlF}_{3}$ flux clearly improved the spreadability and wettability of $\mathrm{Zn}-2 \mathrm{Al}$ filler metal on the base metal. It was found that the maximum spreading area of $\mathrm{Zn}-2 \mathrm{Al}$ on 5052 aluminum occurred when the concentration of $\mathrm{Ga}_{2} \mathrm{O}_{3}$ was 0.0009 wt.\%. For Q235 steel, the maximum value was $0.003 \mathrm{wt} . \%$. Under this circumstance, the spreading area of $\mathrm{Zn}-2 \mathrm{Al}$ filler metal was approximately $350 \mathrm{~mm}^{2}$ over 5052 aluminum, which was an increase of $75 \%$ compared to the applications of CsF-RbF-AlF 3 flux. Additionally, it was $160 \mathrm{~mm}^{2}$ over Q235 steel, representing an improvement of $122 \%$. However, the spreading area mildly decreased with $\mathrm{Ga}_{2} \mathrm{O}_{3}$ addition continually rising. Based on the above results, the conclusion was that the CsF- RbF- $\mathrm{AlF}_{3}-\mathrm{Ga}_{2} \mathrm{O}_{3}$ flux could be applied to brazing Q235 steel to AA5052 matched with Zn-2Al filler metal, and the additional concentration of $\mathrm{Ga}_{2} \mathrm{O}_{3}$ particle range was $0.0009-0.003 \mathrm{wt}$.\%. In Figure 4, partial spreading images are shown. It was obvious that the spreading area of $\mathrm{Zn}-2 \mathrm{Al}$ filler metal was better with the $\mathrm{Ga}_{2} \mathrm{O}_{3}$ particle added in $\mathrm{CsF}-\mathrm{RbF}-\mathrm{AlF}_{3}$ flux. 


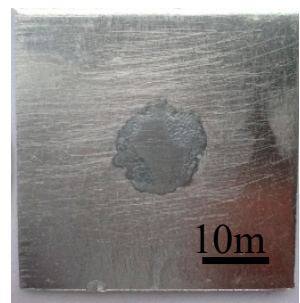

AA5052

0 wt.\%

(a)

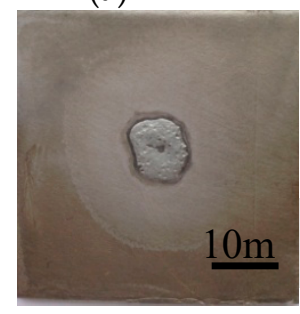

Q235 steel

0 wt.\%

(f)

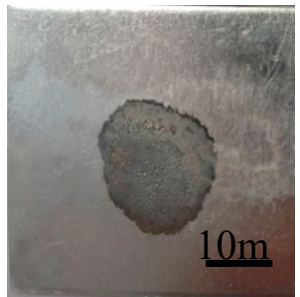

AA5052

0.0005wt.\%

(b)

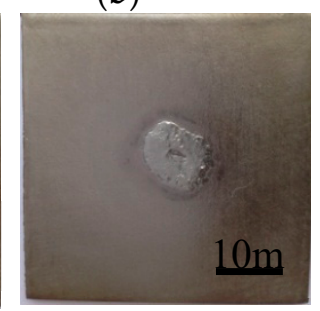

Q235 steel

0.0007wt.\%

(g)

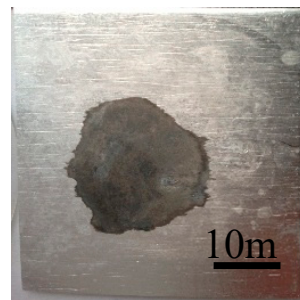

AA5052

0.0009wt.\%

(c)

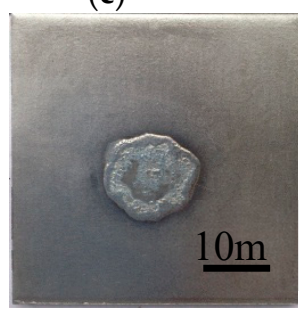

Q235 steel

0.003 wt.\%

(h)

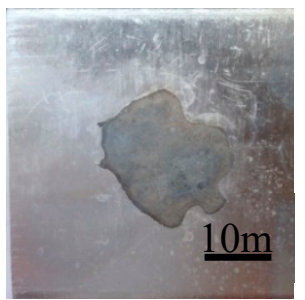

AA5052

0.003 wt. $\%$

(d)

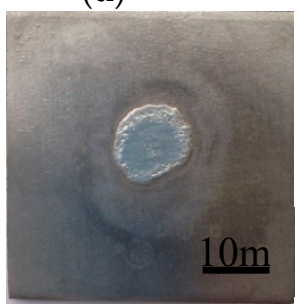

Q235 steel

0.005wt.\%

(i)

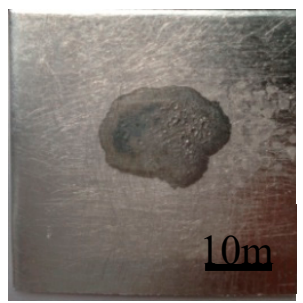

AA5052

0.009wt.\%

(e)

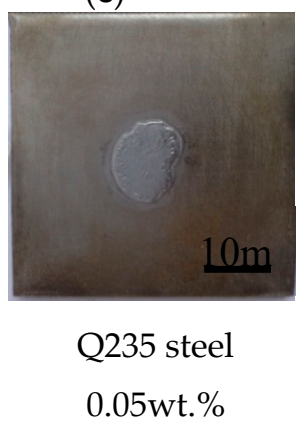

(j)

Figure 4. Spreading tests of $\mathrm{Zn}-2 \mathrm{Al}$ filler metal on base metals with $\mathrm{CsF}-\mathrm{RbF}-\mathrm{AlF}_{3}-\mathrm{xGa}_{2} \mathrm{O}_{3}$ flux: (a-e) 5052 aluminum; (f-i) Q235 low-carbon steel.

\subsection{Interfacial Induction Effect of the $\mathrm{Ga}_{2} \mathrm{O}_{3}$ Particle}

The CsF-RbF- $\mathrm{AlF}_{3}-\mathrm{Ga}_{2} \mathrm{O}_{3}$ flux improved the spreadability and wettability of $\mathrm{Zn}-2 \mathrm{Al}$ filler metal over 5052 aluminum and Q235 steel obviously, but the reason for this was not clear and still needed to be investigated. Therefore, we attempted to employ the theory of interfacial tension [9] to identify some explanations. According to Young's equation, the liquid balanced over a solid surface can be determined by the relationship between the interfacial tension of the solid and liquid. In this investigation, a balance of these interfacial tensions was shown between the base metal and molten flux $\left(\sigma_{s-f l u x}\right)$, molten filler metal and molten flux $\left(\sigma_{1-f l u x}\right)$, and base metal and molten filler metal $\left(\sigma_{s-1}\right)$.

Dezellus [10] mentioned that there were two kinds of ways in which molten metal wets a solid-non-reactive wetting and reactive wetting — and the reaction of a liquid and solid decreases their interfacial tension $\left(\sigma_{\mathrm{s}-1}\right)$ to improve spreading. Because the molten flux reacted with the surface metallic oxides over the base metal to remove it, the explanation for the interfacial reactions discussed in this research was that of reactive wetting. While balancing, the relationship between interfacial tensions is in accordance with Equation (1):

$$
\sigma_{s-f l u x}=\sigma_{l-f l u x} \cdot \cos \theta+\sigma_{s-l}
$$

According to the investigation of Qian [11], alumina reacted with melted $X F-\mathrm{AlF}_{3}(\mathrm{X}=\mathrm{Na}, \mathrm{K}, \mathrm{Rb}$, and $\mathrm{Cs}$ ) flux and formed $\mathrm{AlF}_{3}$ to be dissolved, and the interfacial tension of solid-liquid $\left(\sigma_{\mathrm{s}-1}\right)$ changed from $\mathrm{Zn}$-Al alloy-alumina to $\mathrm{Zn}$-Al alloy-aluminum. Meanwhile, owing to the excellent intersolubility of $\mathrm{Zn}$ and $\mathrm{Al}$ [12], the interfacial tension of the AA5052 and $\mathrm{Zn}-2 \mathrm{Al}$ alloy $\left(\sigma_{\mathrm{s}-1}\right)$ decreased rapidly. Therefore, the spreading area of the $\mathrm{Zn}-2 \mathrm{Al}$ alloy over AA5052 increased obviously.

However, the surface oxide was the maximum obstacle to the brazing process for Q235 steel. No research has reported that the $\mathrm{CsF}_{-} \mathrm{AlF}_{3}$ series flux reacted with iron oxidation immediately. Therefore, the reason why the $\mathrm{Zn}-\mathrm{Al}$ alloy spread over Q235 should be due to the reaction between the $\mathrm{Zn}-\mathrm{Al}$ alloy and oxidation. The thermodynamically calculated results shown in Table 1 indicated that iron 
oxides reacted with Al to form simple substance Fe and dissolved [13]. The phase diagram of Fe-Zn showed that intermetallics, such as FeZn and FeZn ${ }_{4}$, formed below $600{ }^{\circ} \mathrm{C}$. Precisely because of the reaction of Zn and Fe [14], the Zn-2Al filler metal spread over Q235 steel, and their interfacial tension $\left(\sigma^{\prime}{ }_{s-1}\right)$ decreased along with it.

Table 1. Reaction Gibbs energy of iron oxidation and $\mathrm{Al}(\mathrm{T}=873.15 \mathrm{~K})$.

\begin{tabular}{|c|c|c|}
\hline Compounds & Inductions & $\Delta \mathrm{G} / \mathrm{kJ} \cdot \mathrm{mol}^{-1}$ \\
\hline $\mathrm{FeO}$ & $\mathrm{Al}$ & -259.98 \\
\hline $\mathrm{Fe}_{2} \mathrm{O}_{3}$ & $\mathrm{Al}$ & -811.13 \\
\hline $\mathrm{Fe}_{3} \mathrm{O}_{4}$ & $\mathrm{Al}$ & -1041.32 \\
\hline $\mathrm{Ga}_{2} \mathrm{O}_{3}$ & $\mathrm{Al}$ & -575.18 \\
\hline
\end{tabular}

Because of the interfacial reaction, molten $\mathrm{Zn}$-Al filler metal wetted the AA5052 alloy and Q235 steel and spread on them, which broke the balance of Young's equation by reducing the $\sigma_{\mathrm{s}-1}$ shown in Equations (1) and (2). When the gravity was larger than the molten flux, as shown in Table 2, the $\mathrm{Ga}_{2} \mathrm{O}_{3}$ particle settled from molten flux freely to the molten filler metal surface. According to the result of the thermodynamic calculation shown in Table 1, it was found that the $\mathrm{Ga}_{2} \mathrm{O}_{3}$ particle released Ga atoms by reacting with the $\mathrm{Zn}-\mathrm{Al}$ alloy, where $\mathrm{Ga}$ was surface active, and could enrich the surface of filler metal to decrease its interfacial tension between metals $\left(\sigma^{\prime}{ }_{s-1}<\sigma_{s-1}\right)[15]$ :

$$
\sigma_{s-f l u x}<\sigma_{l-f l u x} \cdot \cos \theta+\sigma_{s-l}^{\prime}
$$

Table 2. Density of the compound.

\begin{tabular}{cc}
\hline Compound & Density/g $\cdot \mathbf{m L}^{-\mathbf{1}}$ \\
\hline $\mathrm{Ga}_{2} \mathrm{O}_{3}$ & 6.44 \\
$\mathrm{CsAlF}_{4}$ & 3.7 \\
\hline
\end{tabular}

Considering the activity of molten $\mathrm{Zn}$-2Al filler metal, Ga could be released and tested to demonstrate its release from $\mathrm{Ga}_{2} \mathrm{O}_{3}$. Due to having a similar property to $\mathrm{Al}$ [16], Ga permeated in the molten filler metal spontaneously. The microstructure at the interface of the joint is shown in Figure 5. There is no obvious defect in the interface, the filler metal is fully spread out on the surface of the Q235 steel, and the interface is well-combined. The reaction layers at the interface between the braze joint and base metal differed in thickness: the light gray layer near the braze joint and the dark gray layer near the base metal. The thickness of the interfacial IMC layer highlighted in the pictures was calculated to be $2.82 \mu \mathrm{m}$. The thickness of the light gray layer was $1.56 \mu \mathrm{m}$, and that of the dark gray layer was $1.26 \mu \mathrm{m}$. The EDX results in Figure 6 showed that the weak peak of Ga appeared in the interface of base metal and filler metal. With the increase of $\mathrm{Ga}_{2} \mathrm{O}_{3}$ addition, $\mathrm{Ga}_{2} \mathrm{O}_{3}$ particles displayed more activity by presenting as short rods. Owing to the decrease in $\sigma_{\mathrm{s}-1}$, as well as the interfacial reactions, the original balance was broken and the spreading area increased obviously. A description of the variation of the interfacial tensions is shown as Figure 7. According to the Fe-Al binary phase diagram, the dark gray layer should be the $\theta$-phase Fe-Al intermetallic compound. The $\theta$-phase is in equilibrium with the $\alpha$-Al phase in the $\mathrm{Fe}-\mathrm{Al}$ phase diagram and has a monoclinic crystal structure. The atomic ratio of $\mathrm{Al}$ to Fe ranges from 3 to 3.5 in the $\theta$-phase, and the crystal structure is usually represented by $\mathrm{Fe}_{4} \mathrm{Al}_{13}, \mathrm{FeAl}_{3.2}$, and $\mathrm{FeAl}_{3}$. 


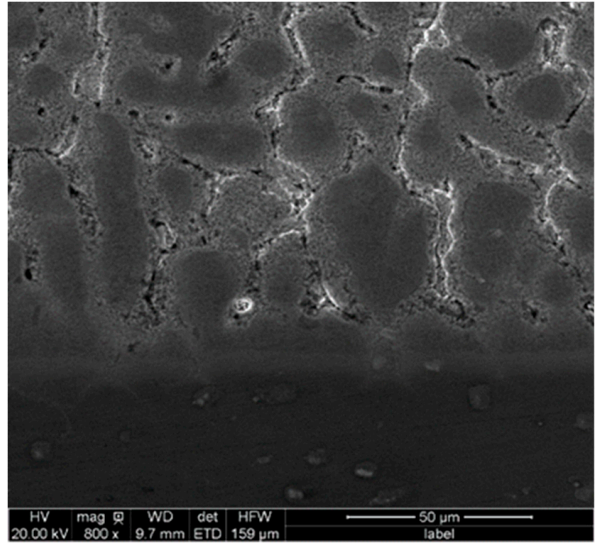

(a)

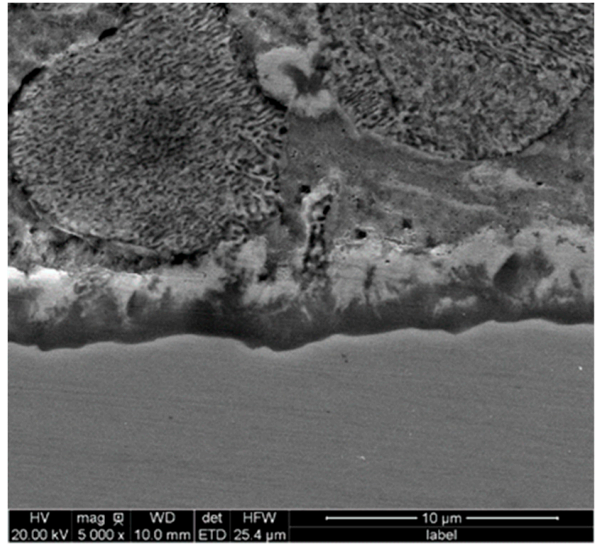

(b)

Figure 5. Microstructure at the interface of the joint: (a) 5052 aluminum; (b) Q235 low-carbon steel.

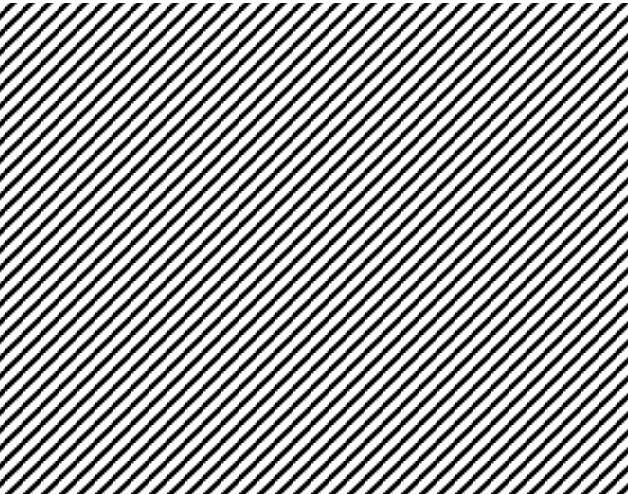

(a)

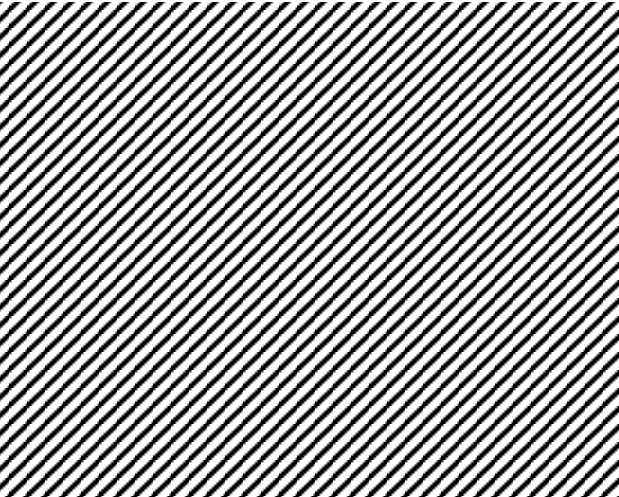

(b)

Figure 6. The interface of AA5052 and Zn-2Al filler metal: (a) SEM scanning image; (b) EDX results of the section.
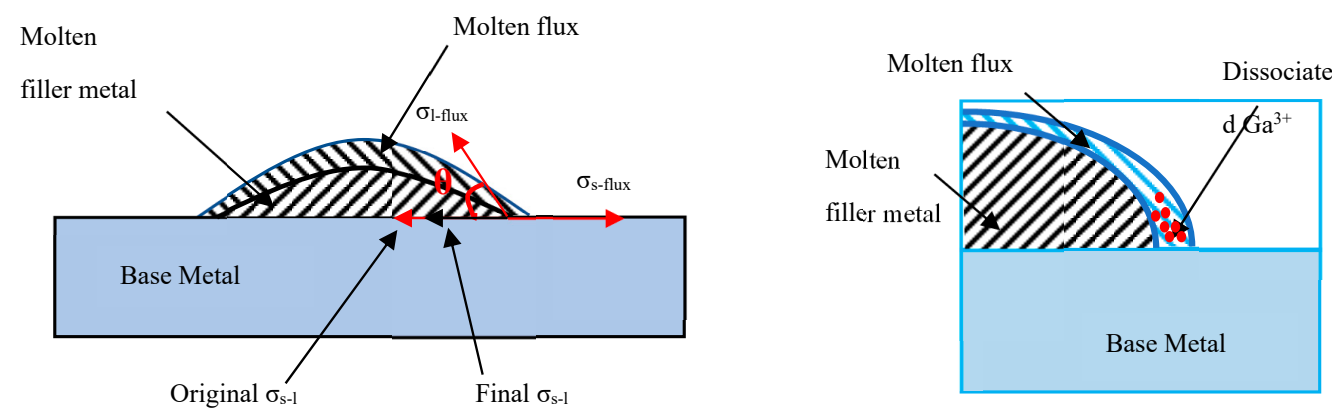

Figure 7. Diagrammatic sketch of $\mathrm{Zn}-\mathrm{Al}$ spreading on base metal.

\subsection{Analysis of the Flux Residue}

An XRD analysis experiment of the flux residue collected from the surface of AA5052 and Q235 steel was carried out. It revealed that the residue products over AA5052 were silicate, oxidation, fluoride, $\mathrm{MgMnSi}_{2} \mathrm{O}_{6}, \mathrm{SiO}_{2}, \mathrm{Al}_{2} \mathrm{SiO}_{5}, \mathrm{MgSiO}_{3}, \mathrm{Al}_{2} \mathrm{O}_{3}, \mathrm{AlF}_{3}, \mathrm{MnF}_{2}, \mathrm{ZnGa}_{2} \mathrm{O}_{4}$, and $\mathrm{Cs}_{11} \mathrm{O}_{3}$; however, they were $\mathrm{MnAlF}_{5}, \mathrm{SiO}_{2}, \mathrm{Al}_{2} \mathrm{O}_{3}, \mathrm{MnF}_{2}, \mathrm{AlF}_{3}, \mathrm{ZnO}, \mathrm{Al}_{2} \mathrm{SiO}_{5}, \mathrm{AlPO}_{4}$, and $\mathrm{FePO}_{4}$ over Q235 steel.

According to a previous report [17], the compounds found over the AA5052 surface were mainly $\mathrm{Mg}_{2} \mathrm{Si}, \mathrm{MgO}, \mathrm{MgAl}_{2} \mathrm{O}_{4}$, and amorphous $\mathrm{Al}_{2} \mathrm{O}_{3}$ and a little $\mathrm{Cu}, \mathrm{Mn}, \mathrm{Cr}$, and Fe. When heating to over $520^{\circ} \mathrm{C}, \mathrm{Mg}$, Mn, and $\mathrm{Si}$ were enriched. The $\mathrm{Cs}_{11} \mathrm{O}_{3}$, silicate, and fluoride were from the reaction between the oxidation over the base metal and $\mathrm{CsF}-\mathrm{RbF}-\mathrm{AlF}_{3}-\mathrm{Ga}_{2} \mathrm{O}_{3}$ flux. However, $\mathrm{ZnGa}_{2} \mathrm{O}_{4}$ was identified from the residue, which certainly came from the reaction of trace amounts of $\mathrm{Ga}_{2} \mathrm{O}_{3}$ in the 
flux. It was previously reported [18] that additional $\mathrm{Ga}$ in the filler metal was enriched on its surface, which meant that $\mathrm{Ga}_{2} \mathrm{O}_{3}$ might have been enriched. It could be speculated that the reaction equation of $\mathrm{ZnGa}_{2} \mathrm{O}_{4}$ can be written as follows:

$$
\mathrm{ZnO}+\mathrm{Ga}_{2} \mathrm{O}_{3} \rightarrow \mathrm{ZnGa}_{2} \mathrm{O}_{4} \Delta \mathrm{G}=-653.15 \mathrm{KJ} / \mathrm{mol}\left(\mathrm{T}=600{ }^{\circ} \mathrm{C}\right)
$$

It was reported that the mechanism through which $\mathrm{CsF}_{-} \mathrm{AlF}_{3}$ flux removed alumina was a process of dissolution and reaction, and the active ingredients were $\mathrm{F}^{-}, \mathrm{HF}, \mathrm{SiF}_{6}{ }^{2-}$, and $\mathrm{Zn}^{2+}$ ions. In this study, a massive $\mathrm{Zn}$ element was present in the filler metal, with a small Si element on the base metal surface, which provided the forming conditions for $\mathrm{Zn}^{2+}$ and $\mathrm{SiF}_{6}{ }^{2-}$ ions during the spreading test. According to the basic principles of the chemical reaction [19], the major flux reaction was listed in Equation (4) [20]. Because of the imperfections of flux preparation technology, a trace amount of $\mathrm{H}_{2} \mathrm{O}$, $\mathrm{NH}_{4} \mathrm{~F}$, and $\mathrm{NH}_{4} \mathrm{AlF}_{4}$ appeared in the CsF-RbF- $\mathrm{AlF}_{3}-\mathrm{Ga}_{2} \mathrm{O}_{3}$ flux, which released active HF during the experiments and accelerated the removal of alumina:

$$
\begin{gathered}
\mathrm{CsAlF}_{4} \stackrel{\Delta}{\leftrightarrow} \mathrm{CsF}+\mathrm{AlF}_{3} \\
\mathrm{NH}_{4} \mathrm{AlF}_{4} \stackrel{\leftrightarrow}{\leftrightarrow} \mathrm{NH}_{4} \mathrm{~F}+\mathrm{AlF}_{3} \\
\mathrm{NH}_{4} \mathrm{~F} \stackrel{\Delta}{\leftrightarrow} \mathrm{NH}_{3}+\mathrm{HF} \\
2 \mathrm{AlF}_{3}+3 \mathrm{H}_{2} \mathrm{O} \stackrel{\leftrightarrow}{\leftrightarrow} \mathrm{Al}_{2} \mathrm{O}_{3}+6 \mathrm{HF} \uparrow
\end{gathered}
$$

However, the XRD result of the residues over Q235 steel was not the same as that for AA5052, which included $\mathrm{MnAlF}_{5}, \mathrm{SiO}_{2}, \mathrm{AlF}_{3}, \mathrm{MnF}_{2}, \mathrm{Al}_{2} \mathrm{SiO}_{5}, \mathrm{Al}_{2} \mathrm{O}_{3}, \mathrm{ZnO}, \mathrm{AlPO}_{4}$, and $\mathrm{FePO}_{4}$. Research has shown that $\mathrm{Fe}_{2} \mathrm{O}_{3}, \mathrm{Fe}_{3} \mathrm{O}_{4}$, and $\mathrm{FeO}$ orderly cover Q235 steel [21]. Therefore, iron oxide removal was the first step for brazing conveniently. It could be found that $\mathrm{F}^{-}$and $\mathrm{HF}$ reacted with Mn compounds and $\mathrm{AlF}_{3}$ to form $\mathrm{MnF}_{2}$ and $\mathrm{MnAlF}_{5} . \mathrm{Fe}_{2} \mathrm{SiO}_{5}$ and $\mathrm{Al}_{2} \mathrm{SiO}_{5}$ were obtained from the reaction of $\mathrm{SiO}_{2}$ and iron oxidation and alumina. Nevertheless, a trifle phosphate, $\mathrm{FePO}_{4}$, and $\mathrm{AlPO}_{4}$ appeared in the $\mathrm{XRD}$ result. As it was shown, there was no phosphorus in the flux, whose component in Q235 was below 0.04 wt. $\%$ [22]. Therefore, $\mathrm{FePO}_{4}$ and $\mathrm{AlPO}_{4}$ were formed by the reactions between metallic oxides and phosphorus in Q235 steel as

$$
2 \mathrm{M}_{2} \mathrm{O}_{3}+4 \mathrm{P}+5 \mathrm{O}_{2} \rightarrow 4 \mathrm{MPO}_{4}(\mathrm{M}=\mathrm{Fe}, \mathrm{Al}) .
$$

Because the content of phosphorus in Q235 was below the XRD detectability, it meant that $\mathrm{P}$ was enriched over the Q235 surface, which is a normal phenomenon that occurs upon heating a P-contained alloy in which phosphorus is lost through burning and phosphorus oxide is formed. Although the existence of $P$ removed a little metallic oxide, it did not remove all oxide films. Therefore, the main reaction mechanism of removing metallic oxides was the reaction between $\mathrm{Al}$ and iron oxidations shown in Table 1.

It was concluded that the main reactions between the $\mathrm{CsF}-\mathrm{RbF}-\mathrm{AlF}_{3}-\mathrm{Ga}_{2} \mathrm{O}_{3}$ flux and surface compounds on the base metal could be described as Equations (3)-(15). Due to the formation of active substances- $-\mathrm{SiF}_{6}{ }^{2-}, \mathrm{HF}$, and $\mathrm{F}^{-}$- the molten flux cleaned up the surface oxidation over AA5052, and active $\mathrm{Al}$ in the filler metal and enriched $\mathrm{P}$ removed the iron oxidation over Q235 steel. Both of these mechanisms improved the spreadability and wettability of molten $\mathrm{Zn}-2 \mathrm{Al}$ filler metal on the base metal.

However, the reactions between silicate and metallic oxide shown in Equation (9) decreased the flux activity by consuming the $\mathrm{CsF}$ in $\mathrm{CsF}_{-} \mathrm{AlF}_{3}$ and inhibited its flowability. Owing to the formation of $\mathrm{Ga}$, the spreadability and wettability of $\mathrm{Zn}-2 \mathrm{Al}$ filler metal were enhanced, despite the activity loss:

$$
28 \mathrm{CsF}+3 \mathrm{SiO}_{2}+10 \mathrm{HF}+\mathrm{MnO} \rightarrow 2 \mathrm{Cs}_{11} \mathrm{O}_{3}+2 \mathrm{Cs}_{2} \mathrm{SiF}_{6}+5 \mathrm{MnF} \mathrm{F}_{2}+5 \mathrm{H}_{2} \mathrm{O} \uparrow
$$




$$
\begin{gathered}
\mathrm{Mg}_{2} \mathrm{Si}+2 \mathrm{O}_{2} \rightarrow 2 \mathrm{MgO}+\mathrm{SiO}_{2} \\
\mathrm{MgAl}_{2} \mathrm{O}_{4}+\mathrm{SiO}_{2} \rightarrow \mathrm{MgSiO}_{3}+\mathrm{Al}_{2} \mathrm{O}_{3} \\
\mathrm{Al}_{2} \mathrm{O}_{3}+\mathrm{SiO}_{2} \rightarrow \mathrm{Al}_{2} \mathrm{SiO}_{5} \\
\mathrm{MnO}+\mathrm{MgO}+2 \mathrm{SiO}_{2} \rightarrow \mathrm{MgMnSi}_{2} \mathrm{O}_{6} \\
\mathrm{Cs}_{2} \mathrm{SiF}_{6} \stackrel{\Delta}{\rightarrow} 2 \mathrm{CsF}+\mathrm{SiF}_{4} \uparrow \\
2 \mathrm{MnO}+4 \mathrm{HF}+\mathrm{AlF}_{3} \rightarrow \mathrm{MnF} F_{2}+\mathrm{MnAlF}_{5}+2 \mathrm{H}_{2} \mathrm{O} \uparrow
\end{gathered}
$$

According to the proposed mechanisms, it was indicated that molten flux reacted with oxidation over base metals to promote the spread of filler metal simultaneously. However, the rapidly effectiveness loss of molten flux decreased the efficiency of alumina removal and further strangled the spreading speed of filler metal, which was mainly due to the consumption of active substances- $\mathrm{SiF}_{6}{ }^{2-}, \mathrm{HF}$, and $\mathrm{F}^{-}$-and the appearance of silicates.

Compared to the lower efficiency of CsF-RbF- $-\mathrm{AlF}_{3}$ flux on iron oxidation, the $\mathrm{Ga}_{2} \mathrm{O}_{3}$ addition obviously improved the activity of the flux because of its enrichment and production of $\mathrm{Ga}$, which helped to decrease the interfacial tension between base metal and molten filler metal. Meanwhile, $\mathrm{Ga}_{2} \mathrm{O}_{3}$ partially reacted with $\mathrm{ZnO}$ to dissolve it, in order to promote the further spreading of molten $\mathrm{Zn}-2 \mathrm{Al}$ filler on the base metal.

\section{Conclusions}

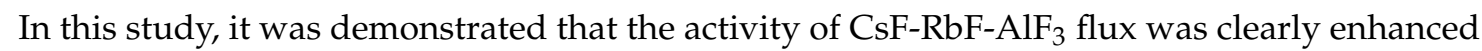
by adding a trace amount of $\mathrm{Ga}_{2} \mathrm{O}_{3}$, promoting the further enlargement of the spreading area of the $\mathrm{Zn}-2 \mathrm{Al}$ filler metal over AA5052 and Q235 steel. The major conclusions were as follows.

The spreading tests showed that the addition of trace amounts of $\mathrm{Ga}_{2} \mathrm{O}_{3}$ in $\mathrm{CsF}-\mathrm{RbF}-\mathrm{AlF}_{3}$ flux promoted the enlargement of the spreading area of $\mathrm{Zn}-2 \mathrm{Al}$ filler metal on both Q235 steel and AA5052 matrix, and the optimal content of $\mathrm{Ga}_{2} \mathrm{O}_{3}$ was $0.001-0.003 \mathrm{wt} . \%$.

The interfacial effect and induction effect of $\mathrm{Ga}_{2} \mathrm{O}_{3}$ improved the flux activity by reacting with $\mathrm{Al}$ atoms to provide $\mathrm{Ga}$ and enriched molten filler metal to decrease its interfacial tension and promote the spreading area increase of molten $\mathrm{Zn}-2 \mathrm{Al}$ filler metal over the matrix. Meanwhile, the phosphorus oxidation and active $\mathrm{Al}$ removed iron oxidation and effectively increased the spreading area of molten $\mathrm{Zn}-2 \mathrm{Al}$ filler metal over the Q235 steel matrix.

As a result of the identified reaction mechanism, it was found that $\mathrm{Ga}_{2} \mathrm{O}_{3}$ partially reacted with

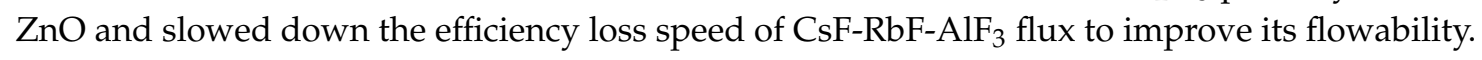

Author Contributions: Conceptualization, S.X.; methodology, J.Z.; software, Z.Y.; validation, Z.Y.; formal analysis, Z.Y.; investigation, Z.Y.; resources, S.X.; data curation, Z.Y.; writing-original draft preparation, Z.Y.; writing-review and editing, Z.Y.; visualization, Z.Y.; supervision, J.Y.; project administration, J.Y.; funding acquisition, S.X. All authors have read and agreed to the published version of the manuscript.

Funding: This work was funded by the National Natural Science Foundation of China, Grant No. 51375233 and the Priority Academic Program Development of Jiangsu Higher Education Institutions (PAPD).

Acknowledgments: We gratefully acknowledge the support of Jiangsu Higher Education Institutions for providing a scholarship for Zhen Yao. Songbai Xue acknowledges financial support from the National Natural Science Foundation of China, Grant No. 51375233.

Conflicts of Interest: The authors declare no conflicts of interest.

\section{References}

1. Cheng, F.J.; Yang, J.X.; Zhao, H.W.; Zhang, G.X.; Huang, J.L.; Long, W.M. Relationship between phase structure and melting characteristics of low cesium $\mathrm{KF}-\mathrm{CsF}-\mathrm{AlF}_{3}$ aluminum flux. Trans. China Weld. Inst. 2013, 34, 5-8. 
2. Cheng, F.J.; Jin, W.S.; Wang, Y.; Wang, D.P. The Chemical Reactions in Solution Synthesis of Aluminum Alloy Brazing Fluorate Flux. Adv. Mater. Res. 2011, 291, 924-928. [CrossRef]

3. Xu, Z.W.; Yan, J.C.; Wang, C.; Yang, S.Q. Substrate oxide undermining by a Zn-Al alloy during wetting of alumina reinforced $6061 \mathrm{Al}$ matrix composite. Mater. Chem. Phys. 2008, 112, 831-837. [CrossRef]

4. Luo, W.; Wang, L.T.; Wang, Q.M.; Gong, H.L.; Yan, M. A new filler metal with low contents of Cu for high strength aluminum alloy brazed joints. Mater. Des. 2014, 63, 263-269. [CrossRef]

5. Ji, F.; Xue, S.B.; Dai, W. Reliability studies of $\mathrm{Cu} / \mathrm{Al}$ joints brazed with $\mathrm{Zn}-\mathrm{Al}-\mathrm{Ce}$ filler metals. Mater. Des. 2012, 42, 156-163.

6. Yang, J.L.; Xue, S.B.; Xue, P.; Lv, Z.P.; Dai, W.; Zhang, J.X. Development of novel CsF-RbF-AlF 3 flux for brazing aluminum to stainless steel with $\mathrm{Zn}-\mathrm{Al}$ filler metal. Mater. Des. 2014, 64, 110-115. [CrossRef]

7. Xiao, B.; Wang, D.P.; Cheng, F.J.; Wang, Y. Oxide film on 5052 aluminium alloy: Its structure and removal mechanism by activated $\mathrm{CsF}-\mathrm{AlF}_{3}$ flux in brazing. Appl. Surf. Sci. 2015, 337, 208-215. [CrossRef]

8. Ma, F.; He, J.H.; Liang, C. Influence of $\mathrm{Ga}_{2} \mathrm{O}_{3}$ Morphology on Synthesis of YAGG: $\mathrm{Ce}^{3+}$ Phosphor Powders by Solid-state Reaction Method. Guangzhou Chem. Ind. Technol. 2018, 19, 36-38.

9. Weber, C.; Stanjek, H. Energetic and entropic contributions to the work of adhesion in two-component, three-phase solid-liquid-vapour systems. Coll. Surf. A Physicochem. Eng. Asp. 2014, 441, 331-339. [CrossRef]

10. Dezellus, O.; Eustathopoulos, N. Fundamental issues of reactive wetting by liquid metals. J. Mater. Sci. 2010, 45, 4256-4264. [CrossRef]

11. Qian, H.; GAO, H.; Sun, B. Recent Researches and Development of Brazing Flux for Aluminum. Mater. Rev. 2007, 12, 76-78.

12. Osório, W.R.; Garcia, A. Modeling dendritic structure and mechanical properties of $\mathrm{Zn}-\mathrm{Al}$ alloys as a function of solidification conditions. Mater. Sci. Eng. A 2002, 325, 103-111. [CrossRef]

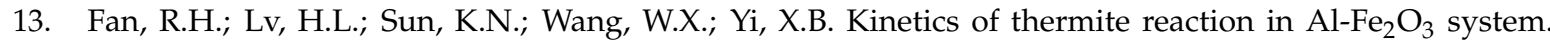
Thermochim. Acta 2006, 440, 129-131. [CrossRef]

14. Dong, H.; Yang, L.; Dong, C.; Kou, S. Improving arc joining of Al to steel and Al to stainless steel. Mater. Sci. Eng. A 2012, 534, 424-435. [CrossRef]

15. Zhao, H.T.; Shi, Y.Q.; Tian, M. Investigation on the Effect of the Substrate Temperature on the Photoelectric Properties of the Ga Doped ZnO Film. Mater. Sci. Forum 2016, 852, 1066-1069. [CrossRef]

16. Guo, S.L.; Li, D.F.; Wu, X.P.; Xu, X.Q.; Du, P.; Hu, J. Characterization of hot deformation behavior of a $\mathrm{Zn}-10.2 \mathrm{Al}-2.1 \mathrm{Cu}$ alloy using processing maps. Mater. Des. 2012, 41, 158-166. [CrossRef]

17. Zhang, J.X.; Xue, S.B.; Xue, P.; Liu, S. Thermodynamic reaction mechanism of the intermetallic compounds of $\mathrm{Sn}_{\mathrm{x}} \mathrm{Nd}_{\mathrm{y}}$ and $\mathrm{Ga}_{\mathrm{x}} \mathrm{Nd}_{\mathrm{y}}$ in soldered joint of $\mathrm{Sn}-9 \mathrm{Zn}-1 \mathrm{Ga}-0.5 \mathrm{Nd}$. J. Mater. Sci. Mater. Electron. 2015, 26, 3064-3068. [CrossRef]

18. Zhu, H.; Xue, S.B.; Sheng, Z. Effect of alloying elements on intermediate temperature filler metal in stepped welding of 6063 aluminum alloy. Trans. China Weld. Inst. 2009, 30, 33-36.

19. Khan, T.I.; Kabir, M.H.; Bulpett, R. Effect of transient liquid-phase bonding variables on the properties of a micro-duplex stainless steel. Mater. Sci. Eng. A 2004, 372, 290-295. [CrossRef]

20. Davies, G.B.; Krüger, T.; Coveney, P.V.; Harting, J.; Bresme, F. Interface deformations affect the orientation transition of magnetic ellipsoidal particles adsorbed at fluid-fluid interfaces. Soft Matter 2014, 10, 6742-6748. [CrossRef]

21. Wan, Y.; Zhang, D.; Liu, H.Q.; Li, Y.J.; Hou, B.R. Influence of sulphate-reducing bacteria on environmental parameters and marine corrosion behavior of Q235 steel in aerobic conditions. Electrochim. Acta. 2010, 55, 1528-1534. [CrossRef]

22. Wang, X.; Yan, Q.; Li, X. Microstructure and properties of 20 steel pipe joints by transient liquid phase bonding and high temperature brazing. Trans. China Weld. Inst. 2005, 26, 56-60.

(C) 2020 by the authors. Licensee MDPI, Basel, Switzerland. This article is an open access article distributed under the terms and conditions of the Creative Commons Attribution (CC BY) license (http://creativecommons.org/licenses/by/4.0/). 